\title{
Causes of end stage renal failure among haemodialysis patients in Khartoum State/Sudan
}

\author{
Amin S. I. Banaga1* , Elaf B. Mohammed², Rania M. Siddig², Diana E. Salama², Sara B. Elbashir², \\ Mohamed O. Khojali², Rasha A. Babiker ${ }^{3}$, Khalifa Elmusharaf $^{4}$ and Mamoun M. Homeida ${ }^{5}$
}

\begin{abstract}
Background: End stage renal failure (ESRF) has become a major health problem in Sub Saharan Africa (SSA). There were limited data about causes of ESRF in the Sudan.

Methods: This is a cross sectional hospital based descriptive study. The subjects of the study are ESRF adults' patients on regular haemodialysis treatment in 15 haemdoialysis centres in Khartoum State-Sudan. Clinical and epidemiological data were obtained from 1583 patients. The medical files of each patient were reviewed to identify the cause of ESRF. Concerning the causes of ESRF, diabetes was diagnosed based on the past medical history and result of the glucose tolerance test, hypertension was diagnosed based on past history of hypertension based on blood pressure of more than 140/90 $\mathrm{mmHg}$, glomerulonephritis was diagnosed based on results of previous kidney biopsies and on clinical grounds, polycystic kidney disease and obstructive uropathy were diagnosed based on abdominal ultrasound and other imaging modalities, sickle cell anaemia was diagnosed based on the result of haemoglobin electrophoresis, systemic lupus erythematosus was diagnosed based on the clinical criteria in addition to lab results of auto antibodies, and analgesic nephropathy was diagnosed based on past medical history of chronic analgesic drugs usage with no other identifiable risk factors. We included all ESRF patients on regular haemodialysis treatment. We excluded ESRF patients less than 18 years old.
\end{abstract}

Results: The results showed that the mean age of ESRF Patients was $49 \pm 15.8$ (years) and $63.4 \%$ were male and $76.3 \%$ were unemployed. The mean duration of haemodialysis is $4.38 \pm 4.24$ (years). The most common cause of ESRF in our patients was hypertension (34.6\%) followed by chronic glomerulonephritis (17.6\%), diabetes mellitus (12.8\%), obstructive uropathy (9.6\%), autosomal dominant poly cystic kidney disease (ADPKD) (4.7\%), chronic pyelonephritis (4.6\%), analgesic nephropathy (3.5\%). However in (10.7\%) no cause was found. In patient aged less than 40 years old the leading cause of ESRF was glomerulonephritis (29.3\%) followed by hypertension (25\%). In patient aged between 40 to 60 years old the leading cause of ESRF was hypertension (38.5\%) followed by diabetes mellitus (14\%). In patient aged older than 60 years the leading cause of ESRF was hypertension (38.4\%) followed by diabetes mellitus (23.3 \%).

Conclusions: ESRF in Sudan affects the economically productive age group; unemployment rate among ESRF patients is high. The study showed that hypertension is a leading cause of ESRF in Sudan followed by chronic glomerulonephritis. Hypertension and diabetes mellitus are the leading causes of ESRF among patients over 40 years old.

Keywords: Sudan, Khartoum, End stage renal failure, Hypertension, Diabetes, Glomerulonephritis

\footnotetext{
*Correspondence: amin.banaga@gmail.com

${ }^{1}$ Haemodialysis Unit, Department of Medicine and Nephrology,

University of Medical Sciences and Technology, Academy Charity

Teaching Hospital, P.O. Box. 12810, Khartoum, Sudan

Full list of author information is available at the end of the article
} 


\section{Background}

End stage renal failure (ESRF) has become a major health problem in Sub Saharan Africa (SSA). There are limited data on the prevalence and incidence of ESRF in SSA due to lack of renal registries. Several studies pointed out to the magnitude of the problem in SSA. In Nigeria a study reported an increase of hospital admissions because of ESRF from 6 to 16 \% between the years 1989 and 2003 [1]. In Senegal only $8.23 \%$ of ESRF patients receive renal replacement therapy (RRT) [2]. In Ghana, a study pointed out that $5 \%$ of total hospital admissions had renal disease of whom $27.1 \%$ died, usually of ESRF [3]. Hypertension is a leading cause of ESRF in Senegal and Ghana $[4,5]$ while chronic glomerulonephritis is the leading cause in South Africa and Ivory Coast [6, 7].

In Sudan, the estimated incidence of new cases of ESRF patients is $70-140$ per million inhabitants/year [8]. There were limited data about causes of ESRF in Sudan. A small study conducted in Sudan among 61 patients in 1987 reported that the causes of chronic kidney disease (CKD) are chronic glomerulonephritis, obstructive nephropathy, hypertension and diabetes mellitus in that order [9]. Furthermore in study conducted among 100 Sudanese patients, chronic glomerulonephritis was found to be the leading cause of ESRF [10]. Other study conducted in central Sudan in 2009 among 224 ESRF patients found that hypertension (14.3\%) is a leading cause of ESRF followed by obstructive uropathy (11.6\%), glomerulonephritis $(9.8 \%)$, diabetes mellitus $(8 \%)$, however in (53.57 \%) no cause was found [11]. The aim of this study is to update and outline the causes of ESRF in Sudan.

\section{Methods}

\section{Study population and data collection}

This study is a cross sectional hospital based descriptive study. The subjects are ESRF adults' patients on regular haemodialysis treatment in 15 haemdoialysis centres in Khartoum/Sudan. All patients on regular haemodialysis were studied in November 2014 and interviewed by questionnaire focusing on personal and clinical data including (age, address, origin, employment, duration of dialysis, cause of ESRF). The medical files of each patient were reviewed to identify the cause of ESRF.

Concerning the causes of ESRF, diabetes was diagnosed based on the past medical history and result of the glucose tolerance test, hypertension was diagnosed based on past history of hypertension based on blood pressure of more than $140 / 90 \mathrm{mmHg}$, glomerulonephritis was diagnosed based on results of previous kidney biopsies and on clinical grounds, polycystic kidney disease and obstructive uropathy were diagnosed based on abdominal ultrasound and other imaging modalities, sickle cell anaemia was diagnosed based on the result of haemoglobin electrophoresis, systemic lupus erythematosus was diagnosed based on the clinical criteria in addition to lab results of auto antibodies, and analgesic nephropathy was diagnosed based on past medical history of chronic analgesic drugs usage with no other identifiable risk factors.

The research was in compliance of declaration of Helsinki and approved by ethics and research committees in the Ministry of Health/Sudan and local hospitals. An informed consent was obtained from each patient participated in the study.

\section{Inclusion and exclusion criteria}

We included all haemodialysis patients in 15 haemodialysis centres in Khartoum/Sudan between (1/11/2014 and $1 / 12 / 2014)$. We excluded haemodialysis patients less than 18 years old.

\section{Statistical analysis}

Data were analyzed using SPSS 21; results were presented in number, percent, mean and standard deviation.

\section{Results}

A total of 1583 ESRF patients participated in the study. The characteristics of the study population are shown in Table 1. The results showed that the mean age of ESRF Patients was $49 \pm 15.8$ (years) and $63.4 \%$ were male and $76.3 \%$ were unemployed. The mean duration of haemodialysis is $4.38 \pm 4.24$ (years).

The aetiology of ESRF is shown in Table 2. The most common cause of ESRF in our patients was hypertension (34.6\%) followed by chronic glomerulonephritis $(17.6 \%)$, diabetes mellitus (12.8\%), obstructive uropathy (9.6\%), autosomal dominant poly cystic kidney disease (ADPKD) (4.7\%), chronic pyelonephritis (4.6\%), analgesic nephropathy (3.5\%). However in (10.7 \%) no cause was found.

In patient aged less than 40 years old the leading cause of ESRF was glomerulonephritis (29.3\%) followed by hypertension ( $25 \%)$. In patient aged between 40 to 60 years old the leading cause of ESRF was hypertension $(38.5 \%)$ followed by diabetes mellitus (14\%). In patient aged older than 60 years the leading cause of ESRF was hypertension (38.4\%) followed by diabetes mellitus $(23.3 \%)$. The study showed significant relation between age and some aetiologies of ESRF, glomerulonephritis, chronic pyelonephritis, sickle cell anaemia and congenital disease are tend to cause ESRF in younger patients while diabetes mellitus, hypertension and polycystic kidney disease are significantly cause ESRF in older patients (Table 3).

We found no regional differences in causes of ESRF in Sudan (Table 4). 
Table 1 The characteristics of the study population

\begin{tabular}{|c|c|}
\hline Age (years) ${ }^{b}$ & $49 \pm 15.8$ \\
\hline \multicolumn{2}{|l|}{ Gender $^{\mathrm{a}}$} \\
\hline Male & $1004(63.4 \%)$ \\
\hline Female & $579(36.6 \%)$ \\
\hline \multicolumn{2}{|l|}{ Occupation $^{\mathrm{a}}$} \\
\hline Unemployed & $1208(76.3 \%)$ \\
\hline Non professional & $238(15.0 \%)$ \\
\hline Professional & $137(8.4 \%)$ \\
\hline \multicolumn{2}{|l|}{ Origin $^{a}$} \\
\hline Northern Sudan & $438(27.7 \%)$ \\
\hline Central Sudan & $417(26.3 \%)$ \\
\hline Western Sudan (Kordofan) & $270(17.1 \%)$ \\
\hline Western Sudan (Darfour) & $144(9.1 \%)$ \\
\hline Eastern Sudan & $53(3.3 \%)$ \\
\hline Khartoum & $261(16.5 \%)$ \\
\hline \multicolumn{2}{|l|}{ Address $^{\mathrm{a}}$} \\
\hline Khartoum & $624(39.4 \%)$ \\
\hline Omdurman & $547(34.6 \%)$ \\
\hline Khartoum North & $230(14.5 \%)$ \\
\hline East Nile & $147(9.3 \%)$ \\
\hline Outside Khartoum & $35(2.2 \%)$ \\
\hline Duration of haemodialysis (years) ${ }^{b}$ & $4.38 \pm 4.24$ \\
\hline
\end{tabular}

a Number (percentage)

b Mean $\pm S D$

Table 2 Causes of end stage renal failure among study population

\begin{tabular}{lr}
\hline Hypertensive nephropathy & $547(34.6 \%)$ \\
Glomerulonephritis & $278(17.6 \%)$ \\
Diabetic nephropathy & $203(12.8 \%)$ \\
Obstructive uropathy & $152(9.6 \%)$ \\
Polycystic kidney disease & $74(4.7 \%)$ \\
Chronic pyelonephritis & $73(4.6 \%)$ \\
Analgesic nephropathy & $56(3.5 \%)$ \\
Congenital and hereditary diseases & $15(0.9 \%)$ \\
Systemic lupus erytherematosus & $9(0.6 \%)$ \\
Sickle cell anaemia & $7(0.4 \%)$ \\
Unknown & $169(10.7 \%)$ \\
Total & $1583(100 \%)$ \\
\hline
\end{tabular}

Data are numbers (percent)

\section{Discussion}

\section{Characteristics of study population}

CKD is at least 3-4 times more frequent in Africa than in developed countries [12]. Haemodialysis treatment in Sudan is free and paid by the government. There are limited data on the prevalence and causes of ESRF in Sudan apart from few studies. This study included a large population of ESRF patients.
CKD in SSA tends to affect relatively younger individuals [13]. Our result showed that the mean age of ESRF patients is $49 \pm 15.8$ (years) and $47.9 \%$ of ESRF patients are below an age of 50 years. This indicates that ESRF in Sudan affects the economically productive age group, unlike the situation in many developed countries were the mean age of ESRF patients is generally over 60 years [14].

In this study males constitute $63 \%$ of ESRF patients receiving haemodialysis treatment; this is similar to many of other study conducted in Africa, in Ethiopia males constitute $61.5 \%$ of ESRF patients receiving dialysis [15], in Ivory Coast males constitute $61 \%$ of patients [16].

Several studies pointed out an increase rate of unemployment among haemodialysis patients $[17,18]$. In our study $76.3 \%$ of ESRF patients receiving haemodialysis treatment were unemployed; this reflect the financial burden on families of patients on haemodialysis especially in an African country like Sudan.

\section{Causes of ESRF}

In the current study hypertension is a leading cause of ESRF as it is a leading cause in many of SSA countries $[4,5]$. Other study conducted in central Sudan in 2009 among 224 patients found that hypertension is a leading cause of ESRF [11]. Hypertension is considered to be a common health problem in SSA. $33 \%$ of the general population in Malawi were found to be hypertensive [19]. In Uganda the prevalence of hypertension was $22.1 \%$ in men and $20.5 \%$ in women [20]. In Nigeria, $20.8 \%$ of general population found to be hypertensive [21]. Hypertension in SSA has been mounting over the past few decades. A meta analysis of studies conducted between 2000 and 2013 in SSA found that only $18 \%$ of individuals with hypertension were receiving treatment and only $7 \%$ had controlled blood pressure [22]. In other community based Sudanese survey conducted in 2012 found that the prevalence of hypertension in rural areas was 15.8 and $45 \%$ had uncontrolled blood pressure [23].

In this study, chronic glomerulonephritis was found to be the second most frequent cause of ESRF. The previous two published studies conducted in Sudan on 1987 and 1989 found that chronic glomerulonephritis is a leading cause of ESRF $[9,10]$, however both studies were conducted in one centre with small study samples. Our results are relevant to many of SSA where the glomerulonephritis was found to be the second leading cause of ESRF. In Nigeria, $27.8 \%$ of causes of ESRF is attributed to chronic glomerulonephritis [1]. In Ghana, glomerulonephritis is a second leading cause of ESRF [5]. In Senegal, $16 \%$ of ESRF patients are due to chronic glomerulonephritis and consider to be the second leading cause of ESRF following hypertension [4]. The situation 
Table 3 Causes of end stage renal failure according to age

\begin{tabular}{|c|c|c|c|c|c|c|c|}
\hline \multirow{2}{*}{$\begin{array}{l}\text { Causes of end stage renal } \\
\text { failure }\end{array}$} & \multicolumn{2}{|c|}{$<40$ years $(n=463)$} & \multicolumn{2}{|c|}{$40-60$ years $(n=716)$} & \multicolumn{2}{|c|}{$>60$ years $(n=404)$} & \multirow[t]{2}{*}{$P$ value } \\
\hline & Count & $\%$ & Count & $\%$ & Count & $\%$ & \\
\hline Glomerulonephritis & 136 & 29.4 & 100 & 14.0 & 42 & 10.4 & 0.000 \\
\hline Hypertensive nephropathy & 116 & 25.1 & 276 & 38.5 & 155 & 38.4 & 0.000 \\
\hline Obstructive uropathy & 42 & 9.1 & 77 & 10.8 & 33 & 8.2 & 0.333 \\
\hline Chronic pyelonephritis & 39 & 8.4 & 20 & 2.8 & 14 & 3.5 & 0.000 \\
\hline Analgesic nephropathy & 19 & 4.1 & 26 & 3.6 & 11 & 2.7 & 0.538 \\
\hline Diabetic nephropathy & 10 & 2.2 & 99 & 13.8 & 94 & 23.3 & 0.000 \\
\hline Congenital and hereditary diseases & 9 & 1.9 & 5 & 0.7 & 1 & 0.2 & 0.024 \\
\hline Polycystic kidney disease & 8 & 1.7 & 50 & 7 & 16 & 4 & 0.0001 \\
\hline Sickle cell anaemia & 6 & 1.3 & 0 & 0 & 1 & 0.2 & 0.004 \\
\hline Systemic lupus erythematosus & 4 & 0.9 & 4 & 0.6 & 1 & 0.2 & 0.484 \\
\hline
\end{tabular}

Data are numbers (percent)

Table 4 Causes of end stage renal failure according to region

\begin{tabular}{|c|c|c|c|c|c|c|c|}
\hline \multirow[t]{2}{*}{ Causes } & \multicolumn{6}{|l|}{ Region } & \multirow[t]{2}{*}{ Total } \\
\hline & North Sudan & Central Sudan & $\begin{array}{l}\text { Kordofan (West } \\
\text { Sudan) }\end{array}$ & $\begin{array}{l}\text { Darfour (West } \\
\text { Sudan) }\end{array}$ & Eastern Sudan & Khartoum & \\
\hline \multirow[t]{2}{*}{ Hypertension } & 146 & 132 & 112 & 43 & 16 & 98 & 547 \\
\hline & $33.3 \%$ & $31.7 \%$ & $41.5 \%$ & $29.9 \%$ & $30.2 \%$ & $37.5 \%$ & $34.6 \%$ \\
\hline \multirow[t]{2}{*}{ Diabetes mellitus } & 74 & 53 & 23 & 11 & 6 & 36 & 203 \\
\hline & $16.9 \%$ & $12.7 \%$ & $8.5 \%$ & $7.6 \%$ & $11.3 \%$ & $13.8 \%$ & $12.8 \%$ \\
\hline \multirow[t]{2}{*}{ Glomerulonephritis } & 69 & 73 & 48 & 37 & 7 & 44 & 278 \\
\hline & $15.8 \%$ & $17.5 \%$ & $17.8 \%$ & $25.7 \%$ & $13.2 \%$ & $16.9 \%$ & $17.6 \%$ \\
\hline \multirow[t]{2}{*}{ Obstructive uropathy } & 41 & 49 & 21 & 18 & 8 & 15 & 152 \\
\hline & $9.4 \%$ & $11.8 \%$ & $7.8 \%$ & $12.5 \%$ & $15.1 \%$ & $5.7 \%$ & $9.6 \%$ \\
\hline \multirow[t]{2}{*}{ Polycystic kidney disease } & 27 & 17 & 7 & 4 & 4 & 15 & 74 \\
\hline & $6.2 \%$ & $4.1 \%$ & $2.6 \%$ & $2.8 \%$ & $7.5 \%$ & $5.7 \%$ & $4.7 \%$ \\
\hline \multirow[t]{2}{*}{ Chronic pyelonephritis } & 20 & 15 & 13 & 5 & 5 & 15 & 73 \\
\hline & $4.6 \%$ & $3.6 \%$ & $4.8 \%$ & $3.5 \%$ & $9.4 \%$ & $5.7 \%$ & $4.6 \%$ \\
\hline \multirow[t]{2}{*}{ Analgesic nephropathy } & 8 & 18 & 12 & 6 & 1 & 11 & 56 \\
\hline & $1.8 \%$ & $4.3 \%$ & $4.4 \%$ & $4.2 \%$ & $1.9 \%$ & $4.2 \%$ & $3.5 \%$ \\
\hline \multirow{2}{*}{$\begin{array}{l}\text { Systemic lupus } \\
\text { erythrematosus }\end{array}$} & 5 & 1 & 2 & 0 & 1 & 0 & 9 \\
\hline & $1.1 \%$ & $0.2 \%$ & $0.7 \%$ & $0.0 \%$ & $1.9 \%$ & $0.0 \%$ & $0.6 \%$ \\
\hline \multirow[t]{2}{*}{ Sickle cell anaemia } & 1 & 1 & 3 & 0 & 1 & 1 & 7 \\
\hline & $0.2 \%$ & $0.2 \%$ & $1.1 \%$ & $0.0 \%$ & $1.9 \%$ & $0.4 \%$ & $0.4 \%$ \\
\hline \multirow{2}{*}{$\begin{array}{l}\text { Congenital and } \\
\text { hereditary diseases }\end{array}$} & 10 & 4 & 0 & 0 & 0 & 1 & 15 \\
\hline & $2.3 \%$ & $1.0 \%$ & $0.0 \%$ & $0.0 \%$ & $0.0 \%$ & $0.4 \%$ & $0.9 \%$ \\
\hline \multirow[t]{2}{*}{ Unknown } & 37 & 54 & 29 & 20 & 4 & 25 & 169 \\
\hline & $8.4 \%$ & $12.9 \%$ & $10.7 \%$ & $13.9 \%$ & $7.5 \%$ & $9.6 \%$ & $10.7 \%$ \\
\hline Total & 438 (100\%) & 417 (100\%) & 270 (100\%) & $144(100 \%)$ & $53(100 \%)$ & $261(100 \%)$ & 1583 (100\%) \\
\hline
\end{tabular}

is different in South Africa where glomerulonephritis is a leading cause of ESRF [6].

Our result showed that diabetes mellitus was found to be the second leading cause of ESRF among patients over 40 years old. There are limited data on prevalence of diabetes mellitus in Sudan. A community based study conducted in Sudan in 1996 conducted among 1284 subjects found that prevalence of diabetes mellitus was $3.4 \%$ 
[24]. Other study conducted in Dongola in North Sudan found that prevalence of diabetes mellitus was $8.3 \%$ [25]. Diabetes is the leading cause of ESRF in Latin America [26] and in UK black patients [27]. In USA, the incidence of ESRF due to diabetes was 2.6 fold higher among blacks [28]. Diabetes is a second leading cause of ESRF in many of SSA like in Nigeria [29] and in Senegal [30]. The prevalence of diabetic nephropathy in SSA is estimated to be $14-16 \%$ in South Africa, 23.8 \% in Zambia, 9 \% in Sudan, and $6.1 \%$ in Ethiopia [12].

Analgesic nephropathy accounted for a significant minority of causes of ESRF in Sudan. This is because the excessive use of analgesia without doctor's prescription. Analgesic nephropathy first attributed to the habitual use of phenacetin-containing analgesics [31]. Several studies pointed out that an excessive use of analgesic mixtures containing acetaminophen, aspirin, caffeine, or codeine also can be associated with analgesic nephropathy and eventually ESRF $[32,33]$. Several studies also pointed out to the association between the use of single-ingredient analgesics containing acetaminophen or aspirin and CKD [34-36]. A Swedish study conducted in 2001 found that the regular use of acetaminophen or aspirin was associated with a risk of chronic renal failure that was 2.5 times as high as that for nonusers [37]. An American study found that patients use non steroidal anti inflammatory drugs (NSAID) in daily bases were associated with twofold increase risk for CKD [38]. NSAID have been associated with nephrotic syndrome, interstitial nephritis and ESRF [39], despite that patient with CKD should avoid the use of NSAID, still studies found that CKD awareness was not associated with reduction of NSAID usage [40].

In our study, $4.7 \%$ of ESRF patients receiving dialysis are due to autosomal dominant polycystic kidney disease (ADPKD) and it remains the leading hereditary cause of ESRF in Sudan. Results obtained from European registries stated that ADPKD constitute about $9.8 \%$ of ESRF patients receiving RRT [41]. There were limited data about prevalence of ADPKD in Africa. Our data is similar to other African studies. In Morocco, $6.5 \%$ of patients on dialysis are due to ADPKD [42] similar to Libya which is $6.3 \%$ [43]. A hospital study conducted in Senegal found that prevalence of ADPKD was one in 250 patients following in Nephrology Department [44].

Small percentage of adult ESRF patients receiving RRT in Sudan is due to sickle cell anemia. Despite sickle cell anaemia is common in Sudan however they die early. Sickle cell anaemia is associated with renal ischemia, glomerulonephritis, nephrotic syndrome and ESRF $[45,46]$. There is limited data on sickle cell nephropathy in SSA. In USA, $0.11 \%$ of ESRF patients receiving renal replacement therapy are due to sickle cell anemia and $93 \%$ were African-Americans [47].
In our study, we couldn't identify a known cause of ESRF in $10.7 \%$ of patients. This is mostly because of late presentation of patients to the nephrology departments and lack of medical facilities and poor medical follow up of patients in rural areas.

The strength of this study is the inclusion of all ESRF patients receiving haemodialysis treatment in 15 haemodialysis units in Khartoum State/Sudan with a total of 1583 patients participated in the study makes our study has a large sample size, putting in mind that $60 \%$ of ESRF patients in Sudan receive RRT in Khartoum State. Our study has limitations that need to be addressed. In our study, hypertension is a leading cause of ESRF, but in some cases it was difficult to determine is it primary hypertension or secondary to CKD itself? This is because of lack of regular medical follow up in our patients. Other point which need to be discussed is that in this study, identifications of diabetes and hypertension as an aetiology of ESRF can be overestimated, lack of kidney biopsies from these patients that needed it to make sure that there is no other cause of ESRF and make an exact determination of the aetiology of ESRF is difficult, this is because of late presentation of patients and lack of resources. Many studies conducted in developing countries used the same criteria we used to determine the aetiology of ESRF $[48,49]$. Other limitation is that sometimes the medical data about the exact nature of the cause of ESRF are not available especially data regarding kidney biopsies which made the percentage of the unknown cause is slightly increased in our study. In addition, our study conducted in haemodialysis patients but there is no available data about ESRF patients not on RRT.

\section{Conclusions}

ESRF in Sudan affects the economically productive age group; unemployment rate is high among ESRF patients. The study showed that hypertension is a leading cause of ESRF in Sudan followed by chronic glomerulonephritis. Hypertension and diabetes mellitus are the leading causes of ESRF among patients over 40 years old.

\section{Abbreviations \\ ADPKD: autosomal dominant polycystic kidney disease; CKD: chronic kidney disease; ESRF: end stage renal failure; RRT: renal replacement therapy; SSA: Sub Saharan Africa; NSAID: non steroidal anti inflammatory drugs. \\ Authors' contributions \\ ASIB designed the questionnaire, collected the sample, carried out the study, analyzed the data and drafted the manuscript. EBM, RMS, DES, SBE, MOK, and $R A B$, collected the sample and analyzed the data. KE revised the methodol- ogy, statistically analyzed the data and revised the manuscript. MMH directed the study and revised the manuscript. All authors read and approved the final manuscript.}

\section{Author details}

${ }^{1}$ Haemodialysis Unit, Department of Medicine and Nephrology, University of Medical Sciences and Technology, Academy Charity Teaching Hospital, P.O. 
Box. 12810, Khartoum, Sudan. ${ }^{2}$ Department of Nephrology, Academy Charity Teaching Hospital, P.O. Box. 12810, Khartoum, Sudan. ${ }^{3}$ Department of Basic Sciences, Faculty of Medicine, University of Medical Sciences and Technology, P.O. Box. 12810, Khartoum, Sudan. ${ }^{4}$ Epidemiology and Public Health, Faculty of Medicine, Royal College of Surgeon in Ireland RCSI Bahrain, P.O. Box. 15503, Adliya, Bahrain. ${ }^{5}$ Department of Medicine, Faculty of Medicine, University of Medical Sciences and Technology, P.O. Box. 12810, Khartoum, Sudan.

\section{Acknowledgements}

The authors thanks the patients and the staff of all the haemdoialysis centres in Khartoum State/Sudan, for contribution in this study.

\section{Compliance with ethical guidelines}

\section{Competing interests}

The authors declare that they have no competing interests.

Received: 15 January 2015 Accepted: 21 September 2015

Published online: 29 September 2015

\section{References}

1. Arogundade F, Sanusi A, Hassan M, Akinsola A. The pattern, clinical characteristics and outcome of ESRD in lle-lfe, Nigeria: is there a change in trend? Afr Health Sci. 2011;11(4):594-601.

2. Diouf B, Niang A, Ka E, Badiane M, Moreira DT. Chronical renal failure in one Dakar Hospital Department. Dakar Med. 2003;48(3):185-8.

3. Plange-Rhule J, Phillips R, Acheampong J, Saggar-Malik A, Cappuccio F, Eastwood J. Hypertension and renal failure in Kumasi, Ghana. J Hum Hypertens. 1999;13(1):37-40.

4. Diouf $B, K a$ E, Niang A, Diouf M, Mbengue M, Diop T. Etiologies of chronic renal insufficiency in a adult internal medicine service in Dakar. Dakar Med. 2000;45(1):62-5.

5. Matekole M, Affram K, Lee S, Howie A, Michael J, Adu D. Hypertension and end-stage renal failure in tropical Africa. J Hum Hypertens. 1993;7(5):443-6.

6. Du Toit E, Pascoe M, MacGregor K, Thomson P. Combined report on maintenance dialysis and transplantation in the Republic of South Africa. In: South African dialysis and transplantation registry report, ed. Cape Town, South Africa; 1994.

7. Diallo A, Niamkey E, Beda YB. Chronic renal insufficiency in Cote d'Ivoire: study of 800 hospital cases. Bull Soc Pathol Exot (1990). 1997;90(5):346-8.

8. Suliman S, Beliela M, Hamza H. Dialysis and transplantation in Sudan. Saudi J Kidney Dis Transplant. 1995;6(3):312.

9. Osman E, Abboud O, Danielson B. Chronic renal failure in Khartoum, Sudan. Upsala J Med Sci. 1987;92(1):65-73.

10. Abboud O, Osman E, Musa A. The aetiology of chronic renal failure in adult Sudanese patients. Ann Trop Med Parasitol. 1989;83(4):411-4.

11. Elsharif $M$, Elsharif E. Causes of end-stage renal disease in Sudan: a singlecenter experience. Saudi J Kidney Dis Transplant. 2011;22(2):373.

12. Naicker S. End-stage renal disease in sub-Saharan Africa. Ethn Dis. 2009;19(1):13

13. Arogundade FA, Barsoum RS. CKD prevention in Sub-Saharan Africa: a call for governmental, nongovernmental, and community support. Am J Kidney Dis. 2008;51(3):515-23.

14. Stel VS, Kramer A, Zoccali C, Jager KJ. The 2007 ERA-EDTA registry annual report-a precis. NDT Plus. 2009:sfp126.

15. Shibiru T, Gudina EK, Habte B, Deribew A, Agonafer T. Survival patterns of patients on maintenance hemodialysis for end stage renal disease in Ethiopia: summary of 91 cases. BMC Nephrol. 2013;14(1):127.

16. Ackoundou-N'Guessan K, Lagou D, Tia M, Gnionsahe D, Guei M. Risk factors for chronic renal failure in Ivory coast: a prospective study of 280 patients. Saudi J Kidney Dis Transplant. 2011;22(1):185.

17. Helanterä I, Haapio M, Koskinen P, Grönhagen-Riska C, Finne P. Employment of patients receiving maintenance dialysis and after kidney transplant: a cross-sectional study from Finland. Am J Kidney Dis. 2012;59(5):700-6.

18. Blake C, Codd MB, Cassidy A, O'Meara YM. Physical function, employment and quality of life in end-stage renal disease. J Nephrol. 1999;13(2):142-9.
19. Msyamboza KP, Ngwira B, Dzowela T, Mvula C, Kathyola D, Harries AD, Bowie C. The burden of selected chronic non-communicable diseases and their risk factors in Malawi: nationwide STEPS survey. PLoS One. 2011;6(5):e20316.

20. Mondo CK, Otim MA, Akol G, Musoke R, Orem J. The prevalence and distribution of non-communicable diseases and their risk factors in Kasese district, Uganda: cardiovascular topics. Cardiovasc J Afr. 2013;24(3):52-7.

21. Oladapo O, Salako L, Sodiq O, Shoyinka K, Adedapo K, Falase A. A prevalence of cardiometabolic risk factors among a rural Yoruba south-western Nigerian population: a population-based survey: cardiovascular topics. Cardiovasc J Afr. 2010;21(1):26-31.

22. Ataklte F, Erqou S, Kaptoge S, Taye B, Echouffo-Tcheugui JB, Kengne AP. Burden of undiagnosed hypertension in Sub-Saharan Africa: a systematic review and meta-analysis. Hypertension. 2014. HYPERTENSIONAHA.114.04394.

23. Balla SA, Abdalla AA, Elmukashfi TA, Ahmed HA. Hypertension among rural population in four States: Sudan 2012. Global J Health Sci. 2014;6(3):p206.

24. Elbagir MN, Eltom MA, Elmahadi EM, Kadam IM, Berne C. A populationbased study of the prevalence of diabetes and impaired glucose tolerance in adults in northern Sudan. Diabetes Care. 1996;19(10):1126-8.

25. Elbagir M, Eltom M, Elmahadi E, Kadam I, Berne C. A high prevalence of diabetes mellitus and impaired glucose tolerance in the Danagla community in northern Sudan. Diabet Med. 1998;15(2):164-9.

26. Cusumano A, Garcia-Garcia G, Di Gioia C, Hermida O, Lavorato C, Carreno CA, Torrico MP, Batista PB, Romao JE, Badal HP, et al. End-stage renal disease and its treatment in Latin America in the twenty-first century. Ren Fail. 2006;28(8):631-7.

27. Fernandes PF, Ellis PA, Roderick PJ, Cairns HS, Hicks JA, Cameron JS. Causes of end-stage renal failure in black patients starting renal replacement therapy. Am J Kidney Dis. 2000;36(2):301-9.

28. Cowie CC, Port FK, Wolfe RA, Savage PJ, Moll PP, Hawthorne VM. Disparities in incidence of diabetic end-stage renal disease according to race and type of diabetes. N Engl J Med. 1989;321(16):1074-9.

29. Naicker S. End-stage renal disease in sub-Saharan and South Africa. Kidney Int. 2003;63:S119-22.

30. Seck SM, Doupa D, Guéye L, Dia CA. Epidemiology of chronic kidney disease in northern region of Senegal: a community-based study in 2012. Pan Afr Med J. 2014;18:307.

31. Spuhler O, Zollinger HU. Chronic interstitial nephritis. Zeitschrift fur klinische Medizin. 1953;151(1):1-50.

32. Buckalew JRVM, Schey HM. Renal disease from habitual antipyretic analgesic consumption: an assessment of the epidemilogic evidence. Medicine. 1986;65(5):291-303.

33. Henrich WL, Agodoa LE, Barrett B, Bennett WM, Blantz RC, Buckalew VM $J r$, D'Agati VD, DeBroe ME, Duggin GG, Eknoyan G. Analgesics and the kidney: summary and recommendations to the Scientific Advisory Board of the National Kidney Foundation from an ad hoc Committe of the National Kidney Foundation. Am J Kidney Dis. 1996;27(1):162-5.

34. Sandler DP, Smith JC, Weinberg CR, Buckalew VM Jr, Dennis VW, Blythe WB, Burgess WP. Analgesic use and chronic renal disease. N Engl I Med. 1989;320(19):1238-43.

35. Morlans M, Laporte J, Vidal X, Cabeza D, Stolley P. End-stage renal disease and non-narcotic analgesics: a case-control study. Br J Clin Pharmacol. 1990;30(5):717-23.

36. Perneger TV, Whelton PK, Klag MJ. Risk of kidney failure associated with the use of acetaminophen, aspirin, and nonsteroidal antiinflammatory drugs. N Engl J Med. 1994;331(25):1675-9.

37. Fored CM, Ejerblad E, Lindblad P, Fryzek JP, Dickman PW, Signorello LB, Lipworth L, Elinder C-G, Blot WJ, McLaughlin JK. Acetaminophen, aspirin, and chronic renal failure. N Engl J Med. 2001;345(25):1801-8.

38. Sandler DP, Burr FR, Weinberg CR. Nonsteroidal anti-inflammatory drugs and the risk for chronic renal disease. Ann Intern Med. 1991;115(3):1-165.

39. Kleinknecht D. Interstitial nephritis, the nephrotic syndrome, and chronic renal failure secondary to nonsteroidal anti-inflammatory drugs. Semin Nephrol. 1995;1995:228-35.

40. Plantinga L, Grubbs V, Sarkar U, Hsu C-Y, Hedgeman E, Robinson B, Saran R, Geiss L, Burrows NR, Eberhardt M. Nonsteroidal anti-inflammatory drug use among persons with chronic kidney disease in the United States. Ann Fam Med. 2011;9(5):423-30. 
41. Spithoven EM, Kramer A, Meijer E, Orskov B, Wanner C, Abad JM, Aresté $\mathrm{N}$, de la Torre RA, Caskey F, Couchoud C. Renal replacement therapy for autosomal dominant polycystic kidney disease (ADPKD) in Europe: prevalence and survival — an analysis of data from the ERA-EDTA Registry. Nephrol Dial Transplant. 2014;29(suppl 4):iv15-25.

42. Bourquia A. Autosomal dominant polycystic kidney disease (ADPKD). in Morocco. Multicenter study about 308 families. Nephrologie. 2001;23(2):93-6.

43. Alashek WA, Mclntyre CW, Taal MW. Epidemiology and aetiology of dialysis-treated end-stage kidney disease in Libya. BMC Nephrol. 2012;13(1):33.

44. Fary Ka E, Seck S, Niang A, Cisse M, Diouf B. Patterns of autosomal dominant polycystic kidney diseases in black Africans. Saudi J Kidney Dis Transplant. 2010;21(1):1-81.

45. Ataga Kl, Derebail VK, Archer DR: The glomerulopathy of sickle cell disease. Am J Hematol. 2014;89:907-14.
46. Powars DR, Elliott-Mills DD, Chan L, Niland J, Hiti AL, Opas LM, Johnson C. Chronic renal failure in sickle cell disease: risk factors, clinical course, and mortality. Ann Intern Med. 1991;115(8):614-20.

47. Abbott K, Hypolite I, Agodoa L. Sickle cell nephropathy at end-stage renal disease in the United States: patient characteristics and survival. Clin Nephrol. 2002;58(1):9-15.

48. Afshar R, Sanavi S, Salimi J. Epidemiology of chronic renal failure in Iran: a four year single center experience. Saudi J Kidney Dis Transplant. 2007;18(2):191.

49. Madala N, Thusi G, Assounga AG, Naicker S. Characteristics of South African patients presenting with kidney disease in rural KwaZulu-Natal: a cross sectional study. BMC Nephrol. 2014;15(1):61.

\section{Submit your next manuscript to BioMed Central} and take full advantage of:

- Convenient online submission

- Thorough peer review

- No space constraints or color figure charges

- Immediate publication on acceptance

- Inclusion in PubMed, CAS, Scopus and Google Scholar

- Research which is freely available for redistribution

Submit your manuscript at

www.biomedcentral.com/submit 